At-Taradhi: Jurnal Studi Ekonomi

Volume XI Nomor 2, Desember 2020

P-ISSN: 1979-3804, E-ISSN: 2548-9941

\title{
Analisis Minat Mahasiswa Universitas Islam Negeri Antasari Banjarmasin dalam Berinvestasi di Pasar Modal
}

\section{Muhammad Noval}

Fakultas Ekonomi dan Bisnis Islam, Universitas Islam Negeri Antasari, Indonesia. Email: noval@,uin-antasari.ac.id

\section{Mujahid}

PT. BFI Finance Indonesia, Tbk. E-mail: muzahidmuhammad70@gmail.com

\section{Noor Sari}

PT. Carmel Anugerah Mandiri, Indonesia. E-mail: noor.sari16@gmail.com

\section{ARTICLE INFO}

Kata Kunci:
Investasi; Minat; Pasar
Modal
Cara Sitasi:
Noval, Muhammad,
Mujahid dan Noor
Sari. "Analisis Minat
Mahasiswa
Universitas Negeri
Antasari Banjarmasin
dalam Berinvestasi di
Pasar Modal.” At-
Taradhi: Jurnal Studi
Ekonomi 11, no. 2
(2020): 104-119.

\begin{abstract}
The purpose of this research was to determine the factors that influence the interest of FEBI UIN Antasari students for invest on the capital market, and to find out the perspectives of academics and practitioners on how to develop investment among students. The population in this study were 428 students of FEBI UIN Antasari who had become investors with a sample size of 81 students who were obtained using the Slovin formula with a standard error of $10 \%$, as well as additional data that were analyzed qualitatively using 3 academics and 2 practitioners in the capital market. The data were processed using quantitative and qualitative methods of analysis that adapts to the conditions in the field that generate a response to the problems studied. The results explain the more dominant factors that cause students to be interested in investing in the capital market, namely motivation, followed by the risk recognition, learning, perception, income and learning factors. As well as the suggestions and opinions of academics and practitioners on how to increase the interest in investing in the stock market by the students is to increase buman resources in the campus, increased support facilities, apply learning theory direct practice and the existence of the program or policy made by the leadership of the campus in increasing interest students invest in the capital market.
\end{abstract}

Tujuan penelitian ini adalah untuk mengetahui faktor yang mempengaruhi minat mahasiswa FEBI UIN Antasari terhadap investasi di pasar modal, dan mengetahui perspektif akademisi dan praktisi tentang cara pengembangan investasi di kalangan mahasiswa. Populasi dalam penelitian ini adalah mahasiwa FEBI UIN Antasari yang sudah menjadi investor berjumlah 428 orang mahasiswa dengan jumlah sampel sebanyak 81 orang mahasiswa yang didapatkan dengan menggunakan rumus slovin dengan standar error $10 \%$, serta tambahan data yang dianalisis secara kualitatif dengan menggunakan 3 orang akademisi dan 2 orang praktisi di pasar modal. Data diolah secara kuantitatif dan kualitatif sesuai karakteristik kedua rumusan. Hasil riset menunjukkan bahwa faktor yang lebih dominan penyebab mahasiswa berminat untuk melakukan investasi di Pasar Modal yaitu Motivasi, kemudian diikuti oleh faktor Pengenalan Risiko, Pembelajaran, Persepsi, Pendapatan dan Pembelajaran. Adapun saran dari akademisi dan praktisi untuk meningkatkan minat mahasiswa berinvestasi di pasar modal yaitu dengan meningkatkan sumber daya manusia di kampus, memperbanyak fasilitas pendukung, menerapkan pembelajaran teori praktik langsung serta 
adanya program ataupun kebijakan yang dibuat oleh pimpinan kampus dalam meningkatkan minat mahasiswa berinvestasi di pasar modal.

\section{Pendahuluan}

Pengertian investasi yang dijelaskan dalam kamus istilah pasar modal dan keuangan menyebutkan bahwa investasi merupakan penanaman modal atau berupa uang pada sebuah proyek atau perusahaan dengan tujuan mengharap imbal hasil berupa keuntungan. sedangkan pasar modal didefinisikan sebagai tempat terjadinya transaksi penjualan saham dan obligasi dengan tujuan mendapatkan tambahan dana dari hasil penjualan instrumen tersebut sehingga dapat digunakan untuk memperkuat perusahaan. ${ }^{1}$

Nilai investasi dengan jumlah besar apabila dimiliki hanya oleh sedikit pihak akan kurang mendukung peningkatan basis investor domestik, sebagaimana dinyatakan dalam Master Plan Pasar Modal Indonesia tahun 2010-2016 bahwa kekuatan basis investor domestik ditentukan oleh nilai investasi domestik dan jumlah investor domestik. ${ }^{2}$

Berinvestasi di pasar modal mempunyai banyak keuntungan selain aman karena dijamin pemerintah, berinvestasi di pasar modal praktis, mudah, tidak ada biaya perawatan atau biaya administrasi, sangat likuid ketimbang uang yang hanya disimpan di bank yang bisa dikatakan aman dan mudah tetapi pertumbuhannya yang relatif masih lambat. Berinvestasi di pasar modal, pajak paling murah, bisa dilakukan seumur hidup sampai tua, bisa disimpan terus hingga diwariskan. Manfaat yang dapat diperoleh dari investasi di pasar modal tidak saja dapat dirasakan oleh para investor tetapi dapat juga dirasakan oleh segala pihak. Dalam berinvestasi saham investor akan memperoleh keuntungan baik dari pembagian deviden perusahaan maupun dari selisih harga beli dan harga jual saham (capital gain). ${ }^{3}$

Investasi di pasar modal juga menjadi sumber dana berpotensi yang dapat meningkatkan kegiatan perekonomian suatu negara. Salah satu contohnya ialah OJK yang mewakili Indonesia sebagai pemenang penghargaan Global Inclution Award 2017. Pada penutupan akhir 2017 yang lalu, IHSG mengalami kenaikan sebesar 41,61 poin atau 0,66\% menyentuh level 6.355,65. Data tersebut menjelaskan bahwa Indonesia adalah salah satu negara terbaik di dunia dengan pasar modalnya yang semakin berkembang dan semakin likuid.

Perkembangan yang sangat pesat dari wahana investasi alternatif lain di Indonesia yaitu industri pasar modal dirasakan setelah dikeluarkannya kebijakan regulasi di Indonesia berkaitan dengan keuangan dan perbankan. Upaya-upaya peningkatan investasi di pasar modal oleh masyarakat di Indonesia selalu dilakukan oleh Bursa Efek Indonesia sebagai Lembaga yang dibentuk pemerintah untuk menjadi wadah yang menyelenggarakan, mengatur dan menjembatani penawaran dan permintaan efek di pasar modal Indonesia. Salah satu gebrakan kebijakan yang sangat populer dan berani dilakukan oleh bursa efek Indonesia adalah perubahan satuan pembelian saham dalam lot, sebelumnya 1 lot saham

\footnotetext{
${ }^{1}$ Lusiana Dewi dan Sri Yunawati, "Analisis Faktor-faktor yang Mempengaruhi Minat Mahasiswa untuk Berinvestasi di Pasar Modal,” AKPEM: Jurnal Akuntansi Keuangan dan Pemerintahan 1, no. 1 (2019): 5.

${ }^{2}$ Masri Situmorang, Riska Natariasari, dan Andreas, "Pengaruh Motivasi Terhadap Minat Berinvestasi di Pasar Modal dengan Pemahaman Investasi dan Usia Sebagai Variabel Moderat,” JOM Fekon 1 (2014): 18.

${ }^{3}$ Gede Etyana Witakusuma, Putu Sukma Kurniawan, dan Edy Sujana, "Faktor-Faktor yang Mempengaruhi Perilaku Mahasiswa dalam Berinvestasi di Pasar Modal (Sebuah Tinjauan Empiris Pada Investor Pemula)," JIMAT (Jurnal Ilmiah Mahasiswa Akuntansi) 9, no. 1 (2018): 12.
} 
terdiri dari 500 lembar saham, dengan kebijakan baru merubah 1 lot saham hanya menjadi 100 lembar saham. Hal ini tentu dimaksudkan untuk kemudahan akses pasar modal bagi seluruh kalangan. Melalui dunia pendidikan, Bursa efek Indonesia juga semakin mensosialisasikan tentang pasar modal kepada masyarakat Indonesia. Pada dasarnya secara operasional pendidikan adalah upaya yang dilakukan untuk mengajarkan serta mengarahkan perilaku individu dalam dimensi atau aspek afektif, kognitif serta prikomotorik ke arah yang sudah dikehendaki. Upaya untuk menciptakan tujuan nasional dalam pembangunan pendidikan sudah tertuang dalam amanat Pembukaan UndangUndang Dasar 1945 yang terdapat pada alenea keempat yaitu "memajukan kesejahteraan umum, mencerdaskan kehidupan bangsa, dan ikut melaksanakan ketertiban dunia".

Pengembangan afektif, kognitif dan psikomotorik menjadi tujuan utama dari Pendidikan berdasarkan sudut pandang peserta didik. Maka dari banyak program kerja serta targettarget yang ingin dicapai oleh bursa efek Indonesia, salah satunya yaitu agenda berkelanjutan yang dilakukan secara berkesinambungan dalam hal sosialisasi, pengenalan dan edukasi kepada sivitas akademika di setiap kampus tentang investasi-investasi dengan instrumen yang ada di pasar modal Indonesia.

Edukasi pasar modal yang dilakukan oleh Bursa Efek Indonesia di setiap kampus merupakan bukti keseriusan perhatian pemerintah untuk kalangan mahasiswa, karena generasi muda diyakini mempunyai minat dan kemampuan yang memadai untuk menjadi investor di pasar modal Indonesia. Dengan adanya launching galeri investasi di berbagai kampus serta keterjangkauan investasi berdasarkan kebijakan terbaru diharapkan memberikan pengaruh besar pada peningkatan jumlah investor dan frekuensi transaksi. Galeri Investasi didirikan oleh PT Bursa Efek Indonesia bekerjasama dengan berbagai perguruan tinggi sebagai salah satu langkah menjaring investor-investor baru dari kalangan mahasiswa. ${ }^{4}$

Institut Agama Islam Negeri (IAIN) Antasari Banjarmasin yang sejak tahun 2017 beralih status menjadi Universitas Islam Negeri (UIN) Antasari Banjarmasin pada tahun akademik 2016/2017 memiliki jumlah mahasiswa aktif D3 dan S1 sebanyak 8.377 orang dengan formulasi 4 Fakultas yang ada dan ditambah dengan 1 Fakultas baru yang mulai efektif pada semester genap di tahun akademik 2017/2018, yaitu Fakultas Ekonomi dan Bisnis Islam (FEBI) yang merupakan pemecahan dari Fakultas Syariah dan Ekonomi Islam (FSEI). Hal ini tentu memberikan peluang yang sangat besar bagi Bursa efek Indonesia untuk semakin melebarkan sayapnya guna semakin mengembangkan dunia pasar modal Indonesia yang dibuktikan dengan langkah nyata berupa relaunching pembukaan galeri investasi Fakultas Syariah dan Ekonomi Islam pada tanggal 30 Maret 2017, yang sekarang juga berganti nama menjadi galeri investasi syariah Fakultas Ekonomi dan Bisnis Islam UIN Antasari.

Mahasiswa Fakultas Ekonomi dan Bisnis Islam dibekali teori pasar modal yang cukup banyak di perkuliahan, ditambah lagi dengan adanya galeri investasi, diharapkan menjadi potensi yang besar untuk menyumbangkan para investor muda karena bersinggungan secara langsung dengan dunia pasar modal, sayangnya harapan ini seakan sirna setelah melihat fakta di lapangan yang mengungkapkan bahwa jumlah mahasiswa sebagai investor khususnya dari Fakultas Ekonomi dan Bisnis Islam sebanyak 428 orang dari total 2.431

\footnotetext{
${ }^{4}$ Lukman Hidayat, Nusa Muktiadji, dan Yoyon Supriadi, "Pengaruh Pengetahuan Investasi Terhadap Minat Mahasiswa Berinvestasi Di Galeri Investasi Perguruan Tinggi," JAS-PT (Jurnal Analisis Sistem Pendidikan Tinggi Indonesia) 3, no. 2 (9 September 2019): 63, https://doi.org/10.36339/jaspt.v3i2.215.
} 
orang mahasiswa yang terdaftar di fakultas atau sekitar 17\% saja dari total mahasiswa aktif, padahal semua mahasiswa dibekali teori tentang investasi di perkuliahan, begitu pula garis besar tentang teknik dalam menganalisis kinerja perusahaan, yang bisa menggunakan analisis teknikal maupun fundamental nova ${ }^{5}$.

Syaeful Bakhri pada tahun 2018 menyebutkan investasi untuk kalangan mahasiswa merupakan proses belajar untuk membekali diri dengan pengetahuan yang sebesarbesarnya dalam upaya untuk mempersiapkan kehidupan ekonomi yang lebih baik untuk diri sendiri dan juga orang di sekitarnya. Ikhtiar dalam melakukan edukasi pasar modal seyogyanya harus dilakukan secara berkelanjutan dan berkesinambungan, karena tidak dapat dipungkiri bahwa salah satu instrumen investasi yang terus berkembang dewasa ini salah satu nya adalah industri pasar modal. ${ }^{6}$

Haris Nandar $\mathrm{dkk}^{7}$ menjelaskan tentang faktor motivasi yang menjadi penyebab utama dari bertumbuhnya minat mahasiswa di IAIN Zawiyah Cot Kala Langsa untuk berinvestasi di pasar modal. Mahasiswa di UIN Sumatera Utara merasakan faktor lain dalam mempengaruhi minat mahasiswa dalam melakukan investasi saham yaitu keberadaan lembaga Galeri Investasi yang ada di Perguruan Tinggi ${ }^{8}$.

Berdasarkan uraian di atas tampak jelas bahwa mahasiswa sebenarnya sudah memiliki modal berikut dukungan fasilitas yang memadai, namun tingkat aplikasi di lapangan menunjukkan bahwa jumlah investor masih cukup rendah. Maka dari penelitian ini diharapkan dapat diketahui faktor yang dapat menjadi kunci minat mahasiswa berinvestasi, sehingga dapat dilakukan program penunjang untuk meningkatkan inklusi pasar modal di kalangan mahasiswa.

\section{Tinjauan Literatur}

\section{Pasar Modal}

\section{a. Definisi Pasar Modal}

Definisi pasar modal dijelaskan dalam undang-undang bab 1, pasal 1, angka 13, UU Republik Indonesia no.8, tahun 1995, yaitu kegiatan yang berkaitan dengan penawaran umum dan perdagangan efek, perusahaan publik yang berhubungan dengan efek yang dikeluarkannya, serta profesi dan lembaga yang berkaitan dengan efek ${ }^{9}$.

\footnotetext{
${ }^{5}$ Muhammad Noval, Rani Raharjanti, dan Musab A M Ali, "Ownership on Islamic Economic Perspective and Director Ownership on Sharia Companies with Moderation Roles of Independent Commissioners," Ikonomika 5, no. 1 (2020): 26.

6 Syaeful Bakhri, "Minat Mahasiswa Dalam Investasi Di Pasar Modal," Al-Amwal: Jurnal Ekonomi dan Perbankan Syariah 10, no. 1 (16 Juni 2018): 146, https://doi.org/10.24235/amwal.v10i1.2846.

${ }^{7}$ Haris Nandar, Mustafa Kamal Rokan, dan M. Ridwan, "Faktor yang Mempengaruhi Minat Mahasiswa Berinvestasi di Pasar Modal Syariah Melalui Galeri Investasi Iain Zawiyah Cot Kala Langsa," KITABAH 2, no. 2 (Juli 2018): 179.

${ }^{8}$ Siti Rahma Hasibuan, "Minat Investasi Mahasiswa Untuk Berinvestasi di Pasar Modal Syariah(Studi Kasus di Galeri Investasi Syariah UIN Sumatera Utara Periode 2017- 2018)" (Medan, Universitas Islam Negeri Sumatera Utara, 2018), 73, http://repository.uinsu.ac.id/id/eprint/4025.

${ }^{9}$ Martalena dan Maya Malinda, Pengantar Pasar Modal (Yogyakarta: Penerbit Andi, 2011).
} 
b. Struktur dan Kelembagaan Pasar Modal

Dalam mengatur kegiatan pasar modal Indonesia maka pemerintah membentuk lembaga-lembaga yang berwenang untuk menata dan mengendalikan kegiatan tersebut sehingga secara tidak langsung dapat memperlancar pergerarakan perekonomian Indonesia. Sturuktur pasar modal Indonesia terdiri atas:

\section{Gambar 1. Struktur Pasar Modal Indonesia ${ }^{10}$}

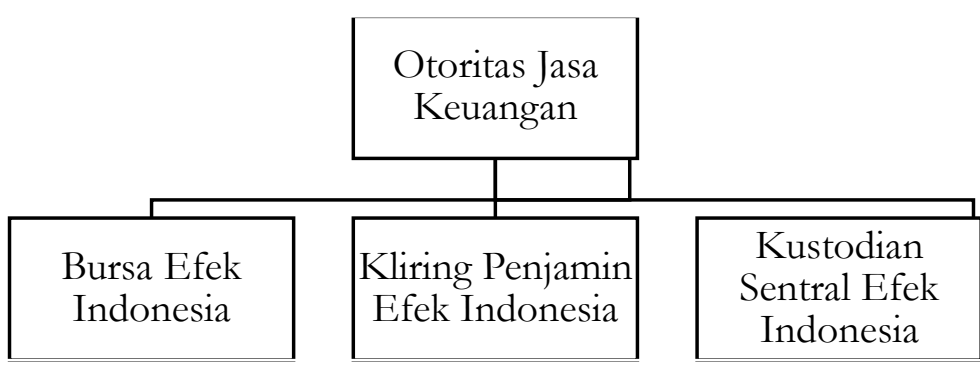

\begin{tabular}{|c|c|c|c|c|}
\hline $\begin{array}{l}\text { Perusahaan } \\
\text { Efek }\end{array}$ & $\begin{array}{l}\text { Lembaga } \\
\text { Penunjang }\end{array}$ & $\begin{array}{l}\text { Profesi } \\
\text { Penunjang }\end{array}$ & Pemodal & $\begin{array}{l}\text {-Emiten } \\
\text {-Perusahaan }\end{array}$ \\
\hline $\begin{array}{l}\text {-Penjamin } \\
\text { Emisi } \\
\text {-Perantara } \\
\text { Pedagang Efek } \\
\text { - Manajer } \\
\text { Investasi }\end{array}$ & $\begin{array}{l}\text {-Biro } \\
\text { Administrasi } \\
\text { Efek } \\
\text {-Bank } \\
\text { Kustodian } \\
\text { - Wali Amanat } \\
\text {-Pemeringkat } \\
\text { Efek }\end{array}$ & $\begin{array}{l}\text {-Akuntan } \\
\text { - Notaris } \\
\text {-Penilai } \\
\text { - Konsultan } \\
\text { Hukum }\end{array}$ & $\begin{array}{l}\text {-Domestik } \\
\text {-Asing }\end{array}$ & -Reksadana \\
\hline
\end{tabular}

Sumber: data primer diolah 2020

Lembaga-lembaga memiliki wewenang di pasar modal Indonesia, diantaranya: ${ }^{11}$

1) Otoritas Jasa Keuangan (OJK)

OJK didirikan dengan tujuan agar semua kegiatan yang dilaksanakan berkaitan dengan bidang jasa keuangan dapat diselenggarakan secara terstruktur, tertib, transparan, adil, terukur dan akuntabel. Sehingga akan tercipta sistem keuangan yang stabil berkembang secara terus-menerus serta terlindunginya hak-hak masyarakat.

2) Bursa Efek Indonesia (BEI)

BEI adalah penelenggara sekaligus penyedia regulasi, sistem dan atau sarana pertemuan antara penjual dan pembeli efek yang pada akhirnya terjadi transaksi perdagangan efek diantara penjual dan pembeli tersebut.

\footnotetext{
${ }^{10}$ OJK, Buku Saku Otoritas Jasa Keuangan, 2 ed. (Jakarta: OJK, t.t.).

${ }^{11} \mathrm{OJK}$.
} 
3) Kliring Penjamin Efek Indonesia (KPEI)

KPEI adalah Lembaga yang bertugas sebagai penyelenggara jasa kliring dan memberikan jaminan atas penyelesaian setiap transaksi yang terjadi di bursa ${ }^{12}$. Kliring yang dimaksud yaitu prosedur yang menentukan hak dan kewajiban efek dan atau nilai uang dari sekuritas akibat dari perdagangan efek yang terjadi di bursa efek Indonesia. Sedangkan maksud dari memberikan jaminan atas penyelesaian setiap transaksi yang terjadi di bursa adalah memberikan kepastian ditunaikannya hak dan kewajiban efek dan atau dana sekuritas yang timbul dari perdagangan efek di bursa.

4) Kustodian Sentral Efek Indonesia (KSEI)

KSEI adalah lembaga yang dibentuk sebagai penyelenggara kegiatan atau pusat kustodian bagi perusahaan efek, bank kustodian, dan pihak-pihak terkait lainnya.

5) Galeri Investasi

Galeri Investasi merupakan sarana yang didirikan bertujuan agar pasar modal dapat dikenalkan secara lebih dini pada kalangan akademisi di perguruan tinggi. Galeri Investasi merupakan kerjasama antara tiga pihak, yaitu pihak Perguruan Tinggi, pihak Bursa Efek Indonesia dan Perusahaan Sekuritas.

Selain itu, juga ada beberapa penunjang lainnya yang memiliki peran penting di pasar modal Indonesia juga dimiliki oleh perusahaan efek (manajer investasi ataupun perantara perdagangan efek dan juga penjamin emisi), lembaga penunjang (biro administrasi efek, wali amanat, kustodian, penilai harga, pemeringkat efek, pelindung dana pemodal atau BAPMI), profesi penunjang (konsultan hukum, akuntan, notaris dan penilai efek), emiten (perusahaan publik atau reksadana), dan pemodal (institusi atau ritel dan lain-lain) ${ }^{13}$.

c. Instrumen Pasar Modal

Pasar modal menawarkan banyak pilihan instrument untuk investasi. Masingmasing instrumen tersebut mempunyai ciri, kelebihan dan kekurangan yang juga berbeda-beda. Beberapa contoh instrument yang tersedia untuk diperdagangkan di pasar modal adalah antara lain saham (stock), obligasi, reksadana dan right dan warran ${ }^{14}$

d. Fungsi, Peran dan Manfaat Pasar Modal

Pasar modal memberikan sumbangsih yang besar terhadap ekonomi suatu negara, peranan besar tersebut dikarenakan pasar modal memiliki fungsi-fungsi yang dapat menunjang perekonomian. Fungsi tersebut adalah fungsi saving, fungsi kekayaan, fungsi likuiditas dan fungsi pinjaman ${ }^{15}$.

\footnotetext{
12 OJK.

${ }^{13}$ Inda Rahadiyan, Hukum Pasar Modal di Indonesia (Yogyakarta: UII Press Yogyakarta, 2014).

14 Martalena dan Malinda, Pengantar Pasar Modal.

15 Martalena dan Malinda.
} 
Pasar modal juga mempunyai manfaat yang besar bagi pihak-pihak yang terkait, diantaranya: ${ }^{16}$

1) Menjadi sarana alokasi dana yang lebih efisien;

2) Sebagai tambahan alternatif wahana investasi;

3) Sebagai wadah yang dapat memberikan kemudahan bagi masyarakat menjadi investor untuk perusahaan yang baik dan memiliki prospek bagus di masa depan;

4) Terjamin bahwa pengelolaan perusahaan dilakukan secara terbuka dan professional; dan

5) Peningkatan aktivitas ekonomi nasional.

e. Landasan Hukum tentang Investasi di Pasar Modal

Landasan yuridis tentang pasar modal di negara Indonesia terdapat dalam beberapa peraturan. Aturan-aturan tersebut, diantaranya adalah:

1) Undang-undang Republik Indonesia Nomer 8 tahun 1995, yang memiliki 18 bab. Semua kegiatan pasar modal dengan prinsp-prinsip syariahnya mengacu pada undang-undang tersebut dan membahas mengenai bursa efek Indonesia, badan pengawas pasar modal, lembaga penunjang pasar modal, emiten dan perusahaan dan lain sebagainya ${ }^{17}$.

2) Standar AAOIFI nomer 21 lanjutan, diperbolehkannya pembelian dan penjualan saham sebuah perusahaan, dengan cara langsung (tunai) maupun secara tangguh. Penyelesaian transaksi secara tangguh diperbolehkan dengan syarat tidak keluar dari prinsip-prinsip syariah.

Sementara itu dari segi agama, Majelis Ulama Indonesia, selaku lembaga yang memiliki otoritas untuk mengeluarkan Fatwa Dewan Syari'ah Nasional yang menjadi himbauan hukum di masyarakat, diantaranya:

1) Fatwa MUI nomor 80 tahun 2011, tentang penerapan prinsip-prinsip syariah yang berlaku dalam mekanisme transaksi jual beli efek yang bersifat ekuitas di pasar modal regular dan Fatwa MUI nomor 05 tahun 2000 tentang transaksi jual beli saham.

2) Fatwa MUI nomor 20 tahun 2000 tentang pedoman berinvestasi dalam instrumen reksa dana syari'ah dan Fatwa MUI nomor 32 tahun 2002 tentang sukuk atau obligasi syariah.

3) Fatwa MUI nomor 40 tahun 2003 berkaitan tentang pasar modal dan pedoman umum penerapan prinsip syariah pada sektor pasar modal dan Fatwa MUI nomor 41 tahun 2004 tentang obligasi syariah jarah $^{18}$.

\footnotetext{
${ }^{16}$ Martalena dan Malinda.

${ }^{17}$ IKAPI, Himpunan Peraturan Pasar Modal (Bandung: Fokusmedia, 2009).

${ }^{18}$ Muhammad, Manajemen Keuangan Syariah: Analisis Fiqh dan Keuangan (Yogyakarta: UPP STIM YKPN, 2016).
} 
Hukum asal dari berinvestasi di pasar modal juga menggunakan kaidah fiqh, yaitu berkaitan dengan muamalah. Akad yang digunakan ialah akad Ba'i AlMusawamah ataupun transaksinya berasaskan pada "Qabdhi Hukmi".

Dalam Al-Quran Surah Al-Baqarah ayat 261 menjelaskan bahwa terdapat contoh nyata dari hasil sebuah investasi dalam bentuk sebutir benih yang dapat tumbuh menjadi tujuh biji dan akhirnya dapat menjadi tujuh ratus biji. Fenomena pertumbuhan ini merupakan gambaran tentang investasi yang dijelaskan dalam firman Allah SWT. Firman tersebut berbunyi:

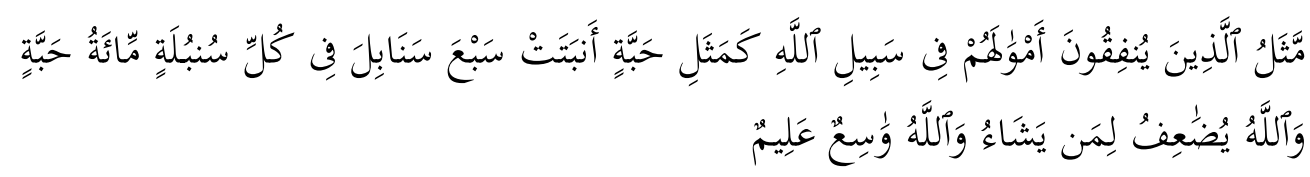

Artinya: "Perumpamaan (nafkeah yang dikeluarkan oleb) orang-orang yang menafkabkan bartanya di jalan Allah adalah serupa dengan sebutir benih yang menumbubkan tujuh bulir, pada tiap-tiap bulir seratus biji. Allah melipat gandakan (ganjaran) bagi siapa yang Dia kehendaki. Dan Allah Maha Luas (karunia-Nya) lagi Maba Mengetahui."

\section{Minat}

\section{a. Definisi Minat}

Besar Bahasa Indonesia mendefinisikan arti dari minat yaitu keinginan atau gairah atau kecondongan hati yang besar pada sesuatu hal. Djaali memberikan penjabaran tentang minat yaitu berkaitan gaya gerak yang memotivasi seseorang untuk beraktifitas yang berhubungan dengan orang lain, benda, kegiatan ataupun pengalaman yang distimulus oleh aktifitas itu sendiri ${ }^{19}$. Kriteria minat seseorang dapat digolongkan menjadi:

1) Rendah. Kriteria rendah terjadi apabila seseorang tidak menginginkan atau tidak suka terhadap sebuah objek.

2) Sedang. Kriteria sedang apabila objek diinginkan oleh seseorang namun bukan dalam jangka waktu dekat.

3) Tinggi. Kriteria tinggi apabila subjek benar-benar menginginkan objek minat dalam waktu dekat.

Menurut Yudrik Jahja ${ }^{20}$, minat mempunyai karakter dan sifat yang khusus, menurutnya minat merupakan sifat privat seseorang, setiap orang memiliki minat yang berbeda-beda satu dengan yang lainnya, minat menghasilkan akibat membeda-bedakan, erat kaitannya dengan motivasi. Minat juga bisa mempengaruhi terhadap objek yang dipelajari, bukan bersifat alamiah dari lahir dan sewaktu-waktu dapat berubah tergantung pada pengalaman, keadaan hati (mood) dan kebutuhan.

\footnotetext{
${ }^{19}$ Desmond Wira, Memulai Investasi Saham (Jakarta: Exceed, 2015).

${ }^{20}$ Yudrik Jahja, Psikologi Perkembangan (Jakarta: Kencana Prenada Media Group, 2011).
} 
b. Faktor- Faktor yang mempengaruhi minat

Indikator-indikator yang dapat digunakan untuk mengukur minat investasi adalah sebagai berikut ${ }^{21}$ :

1) Risiko, dalam hal ini risiko ditunjukkan dengan adanya ketidakpastian dalam suatu kondisi yang dapat diprediksi.

2) Level pendapatan, ditunjukkan dengan adanya keadaan ekonomi bagi investor yang berbeda-beda

3) Motivasi, dalam hal ini ditunjukkan dengan perilaku investor yang berbeda untuk memuaskan kebutuhannya

4) Pengetahuan, dalam hal ini ditunjukkan dengan adanya manfaat yang akan didapatkan oleh investor terkait pengembalian, risiko dan tipe produk investasi.

5) Persepsi, ditunjukkan dengan adanya pilihan atas dasar kesesuaian yang dihendaki tiap investor.

6) Belajar, ditunjukkan dari hasil informasi yang telah didapatkan sebelumnya dari seorang investor agar dapat meningkatkan kualitas untuk menganalisa lebih baik tentang pasar modal.

c. Jenis-Jenis Minat

Banyak ahli mengemukakan jenis-jenis mengenai minat, menurut Carl Safran dalam Fajri (2019) mengklasifikasikan minat menjadi empat jenis: ${ }^{22}$

1) Expressed interest adalah minat yang diekspresikan melalui suatu objek aktivitas.

2) Manifest interest adalah minat yang disimpulkan dari keikutsertaan individu pada suatu kegiatan tertentu.

3) Tested interest adalah minat yang berasal dari pengetahuan dan keterampilan dalam suatu kegiatan.

4) Invored interest adalah dimana minat ini berasal dari daftar aktivitas dan kegiatan yang sama dengan pernyataan.

\section{Metode Penelitian}

Pendekatan kuantitatif menjadi dasar pendekatan dalam penelitian ini, yaitu dengan menggunakan instrumen kuesioner yang dibagikan kepada mahasiswa yang menjadi investor di pasar modal. Data dikumpulkan, dijaring, dan data atau informasi tersebut diolah untuk dicermati dan dianalisis.

\footnotetext{
${ }^{21}$ Reni Karmila, “Analisa Faktor-Faktor yang mempengaruhi minat mahasiswa untuk berinvestasi di pasar modal (Studi Kasus Pada Seluruh Mahasiswa Yang Tercatat Sebagai investro di IDX Kota Jambi)" (Jambi, Universitas Islam Negeri Sulthan Thaha Saifuddin, 2018), http://repository.uinjambi.ac.id/id/eprint/673.

${ }^{22}$ Hayatul Fajri, “Analisis Faktor-Faktor Yang Mempengaruhi Minat Berinvestasi Di Pasar Modal Syariah (Studi Kasus Mahasiswa Program Studi Ekonomi Syariah UIN Ar-Raniry Banda Aceh) Tahun 2018” (Aceh, Universitas Islam Negeri Ar-Raniry, 2018), 134, https://repository.ar-raniry.ac.id/id/eprint/8292/.
} 
Adapun berlokasi penelitian ini yaitu di Fakutas Ekonomi dan Bisnis Islam Universitas Islam Negeri Antasari Banjarmasin. Informasi yang dikumpulkan adalah faktor-faktor dominan yang menjadi alasan mahasiswa berminat berinvestasi di pasar modal, dan tanggapan dari beberapa akademisi mengenai pembelajaran serta masalah terkait pasar modal bagi para mahasiswa di Fakultas Ekonomi dan Bisnis Islam UIN Antasari. Selain itu, riset ini juga berupaya mencari gambaran tentang investasi oleh para praktisi di bidang pasar modal berikut solusi yang dapat ditawarkan untuk memecahkan setiap permasalahan yang terjadi.

Populasi daam penelitian ini yaitu mahasiswa UIN Antasari yang sudah menjadi investor, akademisi dan praktisi. Sampel penelitian untuk menguji minat mahasiswa dalam berinvestasi diambil dari populasi yang berjumlah 428 mahasiswa dengan menggunakan rumus Slovin dengan margin eror 10\%, sehingga didapatkan hasil sebagai berikut:

$$
\mathrm{n}=\frac{\mathrm{N}}{1+\left(\mathrm{N} \cdot \mathrm{e}^{2}\right)}=\frac{428}{1+\left(428 \cdot 0,1^{2}\right)}=81,06
$$

Sehingga diperoleh jumlah sampel untuk pengujian kuantitatif terhadap minat mahasiswa berinvestasi di pasar modal sebanyak 81 orang mahasiswa.

Penelitian ini menggunakan metode statistik deskriptif dalam Teknik analisisnya, yaitu tabel distribusi frekuensi, prosentase, dan mean dengan penggunaan skala likert 1-5 sebagai indikator pengukurannya. Skor penilaian terhadap hasil prosentase ini dibagi menjadi empat kategori: a) $0 \%-25 \%=$ sangat rendah. b) $26 \%-50 \%=$ rendah. c) $51 \%-75 \%=$ tinggi. d) $76 \%-100 \%=$ sangat tinggi.

\section{Hasil dan Pembahasan}

Kuesioner yang dibagikan kepada 81 responden mahasiswa yang sudah menjadi investor menunjukkan hasil sebagai berikut:

Tabel 1. Jenis Kelamin Responden

\begin{tabular}{llll}
\hline No & Jenis Kelamin & Jumlah & Persentasi \\
\hline 1 & Laki-Laki & 27 & $33 \%$ \\
\hline 2 & Perempuan & 54 & $67 \%$ \\
\hline TOTAL & 81 & $100 \%$ \\
\hline
\end{tabular}

Sumber: data diolah penulis, 2020

Dari 81 Responden yang mengisi kuesioner terdiri dari 27 orang laki-laki dan 54 orang perempuan.

Tabel 2. Prodi/Jurusan Responden

\begin{tabular}{llll}
\hline No & Program Studi & Jumlah & Persentasi \\
\hline 1 & Perbankan Syariah & 28 & $35 \%$ \\
\hline 2 & Ekonomi Syariah & 40 & $49 \%$ \\
\hline 3 & Asuransi Syariah & 13 & $16 \%$ \\
\hline TOTAL & 81 & $100 \%$ \\
\hline
\end{tabular}


Sumber: data diolah penulis, 2020

Responden yang berasal dari unsur mahasiswa Fakultas Ekonomi dan Bisnis Islam UIN Antasari Banjarmasin terwakili dari semua program studi, dengan prodi terbesar dalam penyumbang responden berasal dari Pragram Studi Ekonomi Syariah sebesar 49\%, kemudian Perbankan Syariah 35\% dan Asuransi Syariah 16\%.

Tabel 3. Sumber informasi tentang pasar modal

\begin{tabular}{clll}
\hline No & Sumber Informasi & Jumlah & Persentasi \\
\hline 1 & Perkuliahan & 37 & $46 \%$ \\
\hline 2 & Media Sosial (Facebook, Instagram, Twitter, dll) & 13 & $16 \%$ \\
\hline 3 & Media Elektronik (Televisi / Radio) & 1 & $1 \%$ \\
\hline 4 & Media Cetak (Surat Kabar, Majalah, dll) & 0 & $0 \%$ \\
\hline 5 & Galeri Investasi FEBI & 27 & $33 \%$ \\
\hline 6 & Lainnya & 3 & $4 \%$ \\
\hline TOTAL & 81 & $100 \%$ \\
\hline
\end{tabular}

Sumber: data diolah penulis, 2020

Pembelajaran dari perkuliahan menjadi referensi terbesar dalam hal sumber informasi pasar modal yang diterima oleh responden dengan tingkat persentasi $46 \%$, sumber kedua berasal dari Galeri Investasi FEBI dengan proporsi 33\%.

Tabel 4. Instrumen pilihan dalam berinvestasi di pasar modal

\begin{tabular}{llll}
\hline No & Instrumen Investasi & Jumlah & Persentasi \\
\hline 1 & Saham & 67 & $83 \%$ \\
\hline 2 & Obligasi & 0 & $0 \%$ \\
\hline 3 & Reksadana & 14 & $17 \%$ \\
\hline TOTAL & 81 & $100 \%$ \\
\hline Sumber: data diolah penulis, 2020 & &
\end{tabular}

Instrumen saham dalam pasar modal menjadi instrument yang paling diminati dengan mendominasi persentasi sebanyak 83\%, sedangkan instrument obligasi tidak menjadi pilihan investasi di kalangan mahasiswa.

Tabel 5. Faktor-faktor yang mempengaruhi minat berinvestasi di pasar modal

\begin{tabular}{lllll}
\hline No & Indikator & Jumlah Skor & Rata-Rata & Persentasi \\
\hline 1 & Risiko & 308 & 3,80 & $74 \%$ \\
\hline 2 & Level Pendapatan & 284 & 3,51 & $70 \%$ \\
\hline 3 & Motivasi & 336 & 4,15 & $83 \%$ \\
\hline 4 & Pengetahuan & 282 & 3,48 & $70 \%$ \\
\hline 5 & Persepsi & 291 & 3,59 & $72 \%$ \\
\hline
\end{tabular}




\begin{tabular}{lllll}
\hline 6 & Pembelajaran & 298 & 3,68 & $74 \%$ \\
\hline
\end{tabular}

Sumber: data diolah penulis, 2020

Berdasarkan tabel 1.5 digambarkan bahwa Motivasi menjadi faktor terbesar untuk mahasiswa dalam berinvestasi di pasar modal. Hal itu ditunjukkan dari hasil tertinggi yaitu $83 \%$ dengan rata-rata skor 4,15. Sedangkan lima faktor lain hanya tidak mencapai persentasi $75 \%$ dalam mempengaruhi minat mahasiswa berinvestasi di pasar modal.

Berdasarkan data tersebut, terlihat bahwa informasi di perkuliahan sangat efektif dalam meningkatkan literasi mahasiswa dalam hal pasar modal serta tidak luput pula peran dari Galeri Investasi FEBI dalam memberikan edukasi pasar modal dapat memberikan dampak positif pula, hal itu sesuai dengan hasil yang ditunjukkan pada tabel 1.3. Berdasarkan pengetahuan dan informasi yang dimiliki oleh mahasiswa FEBI UIN Antasari Banjarmasin tentang instrumen di pasar modal, pada tabel 1.4, instrumen saham menjadi primadona investasi yang banyak diminati oleh Mahasiswa FEBI UIN Antasari dengan hasil 83\%, sisanya mahasiswa lebih memilih investasi di reksadana dengan persentasi $17 \%$.

Tabel 1.5 menjelaskan dari enam faktor yang dapat mempengaruhi minat mahasiswa untuk berinvestasi di Pasar Modal, faktor Motivasi menjadi faktor paling dominan dengan tingkat $83 \%$ atau masuk dalam kategori sangat tinggi. Mahasiswa memiliki tujuan yang jelas untuk berinvestasi sehingga dari tujuan tersebut menjadi motivasi kuat dalam melakukan investasi di Pasar Modal. Hasil ini sejalan dengan penelitian yang dilakukan oleh Haris Nandar Dkk (2018) di IAIN Zawiyah Cot Kala Langsa yang menyebutkan bahwa faktor motivasi menjadi faktor penentu dalam berinvestasi. ${ }^{23}$ Penelitian lain yang mendukung hasil penelitian ini adalah dari Iqtal Amhalmad dan Agus Irianto pada tahun 2019 yang menyebutkan bahwa semakin tinggi motivasi yang dimiliki oleh mahasiswa untuk berinvestasi, maka akan semakin kuat dan besar keinginan mahasiswa tersebut untuk berinvestasi. ${ }^{24}$ Motivasi investasi juga berpengaruh positif signifikan terhadap minat investasi mahasiswa pada Kompetisi Yuk Nabung Saham 2017. ${ }^{25}$ Sedangkan Faktor lain hanya mendapatkan skor persentasi kurang dari $75 \%$, atau masuk dalam kategori tinggi dalam mempengaruhi minat mahasiswa berinvestasi di pasar modal, dengan hasil yang didapat yaitu Pengenalan Risiko dan Pembelajaran dengan 74\%, Persepsi $72 \%$ serta Pendapatan dan Pembelajaran menjadi faktor terkecil dengan hanya $70 \%$ dalam mempengaruhi minat mahasiswa berinvestasi. Padahal dalam penelitian dari Andriani (2019) faktor return menjadi penentu minat mahasiswa dalam berinvestasi. ${ }^{26}$

Adapun solusi atas permasalahan minimnya keterlibatan mahasiswa yang menjadi investor di FEBI UIN Antasari berdasarkan wawancara terhadap narasumber yang berasal dari

\footnotetext{
${ }^{23}$ Haris Nandar dan Mustafa Kamal Rokan, "Faktor yang Mempengaruhi Minat Mahasiswa Berinvestasi di Pasar Modal Syariah Melalui Galeri Investasi Iain Zawiyah Cot Kala Langsa,” KITABAH 2, no. 2 (2018).

${ }^{24}$ Iqbal Amhalmad dan Agus Irianto, "Pengaruh Pengetahuan Investasi dan Motivasi Investasi Terhadap Minat Berinvestasi Mahasiswa Pendidikan Ekonomi Fakultas Ekonomi Universitas Negeri Padang," Jurnal EcoGen 2, no. 4 (2019): 734-46.

${ }^{25}$ Universitas Trunojoyo Madura dkk., "Minat Investasi Mahasiswa pada Kompetisi Yuk Nabung Saham 2017 di Bursa Efek Indonesia (Pendekatan Mixed Methods)," Journal of research and application: accounting and management 4, no. 1 (1 September 2019), https://doi.org/10.18382/jraam.v4i1.005.

${ }^{26}$ Sri Andriani, "Minat Investasi Saham pada Mahasiswa," Jurnal Ekonomi dan Bisnis Indonesia 4, no. 1 (20 Juli 2019), https://doi.org/10.37673/jebi.v4i1.285.
} 
unsur Akademisi (dosen) FEBI UIN Antasari serta unsur praktisi dari Bursa Efek Indonesia dan Sekuritas yaitus sebagai berikut:

Feby Devina, salah satu pegawai di kantor Bursa Efek Indonesia Kantor Perwakilan Banjarmasin menuturkan bahwa cara untuk meningkatkan keterlibatan mahasiswa dalam melakukan investasi pada instrumen-instrumen yang disediakan pasar modal adalah dengan cara menggencarkan sosialisasi dan follow up kepada para dosen karena dosen juga mempunyai peranan cukup besar dalam membuka pola pikir mahasiswanya disamping juga perlu membentuk kerjasama yang bagus antara Bursa Efek Indonesia, Galeri Investasi dan Sekuritas.

Selaras dengan ungkapan Feby Devina, Jumi Herlita yang merupakan salah seorang dosen di UIN Antasari memberikan pendapat yaitu dalam meningkatkan minat mahasiswa dalam melakukan penanaman modal di Pasar Modal perlu dilakukan beberapa hal, misalnya sosialisasi yang masih perlu ditingkatkan, kerjasama dengan dosen pengampu yang mengajar tentang investasi di pasar modalpun juga bisa dilakukan jika kalian menginginkannya, kerjasama disini bisa dalam bentuk memberikan kesempatan untuk mengenalkan investasi di pasar modal saat kelas berlangsung ataupun memfasilitasi mereka yang ingin belajar investasi di pasar modal dengan cara melakukan kunjungan ke Galeri Investasi.

Sementara itu, peran seorang dosen seolah kembali titik vital dalam meningkatkan keterlibatan mahasiswanya dalam melakukan investasi di dunia pasar modal. Hal ini bisa terlihat dari dua pendapat diatas dan juga ungkapan dari Agus Purnomo, seorang dosen tidak tetap di lingkungan FEBI UIN Antasari mengatakan peningkatan keahlian dosen yang membidangi ini perlu dilakukan, disamping juga perlunya di adakan fasilitas yang bisa menunjang mahasiswa dalam memahami apa itu investasi di Pasar Modal. Bahkan, lebih dalam lagi dia mengatakan jika memungkinkan investasi bisa dijadikan sebagai mata kuliah wajib, seperti yang telah dilakukan salah satu kampus di Yogyakarta yang mengalokasikan 3 SKS yang terdiri atas 2 SKS sebagai pembelajaran teorinya dan 1 SKSnya dijadikan sebagai praktek dari teori tadi.

Lebih lanjut lagi, Haris Faulidi Asnawi salah seorang dosen sekaligus ketua program studi di lingkup FEBI UIN Antasari menyatakan saat ini pihak kampus masih mengusahakan agar ketertarikan mahasiswa berinvestasi di pasar modal bisa meningkat salah satunya adalah mengadakan kerjasama dengan TICMI disamping juga masih banyak kegiatan terstruktur maupun tidak terstruktur yang diadakan oleh perguruan tinggi seperti disusunnya kurikulum yang menyediakan mata kuliah khusus membahas tentang pasar modal.

Menambahkan solusi yang telah dijabarkan oleh beberapa narasumber tadi, Bernanto Pardosi salah seorang praktisi Pasar Modal yang bekerja di salah satu sekuritas ternama di Indonesia mengungkapkan argumentasinya mengenai cara untuk meningkatkan keterlibatan mahasiswa berinvestasi dipasar modal melalui sebuah kegiatan sosialisasi yang bersifat inklusi sehingga dapat menghasilkan output yang contohnya adalah Sekolah Pasar Modal (SPM) yang dilanjutkan dengan adanya kelas aktivasi sebagai sebuah kegiatan bagi calon investor untuk mendapatkan ilmu yang lebih mendalam dan mampu mempraktikannya. 


\section{Penutup}

Berdasarkan uraian permasalahan serta pembahasan yang telah dijelaskan di atas, maka penulis berkesimpulan bahwa mahasiswa FEBI UIN Antasari telah mendapatkan pengetahuan dan ilmu yang memadai tentang investasi di Pasar Modal yang sudah didapatkan dari perkuliahan dan Galeri Investasi FEBI. Faktor Risiko, Pendapatan, Pengetahuan, Persepsi dan Pembelajaran memiliki persentasi yang tinggi dalam minat berinvestasi namun Investasi di Pasar Modal di kalangan mahasiswa FEBI UIN Antasari lebih besar pengaruhnya berasal faktor Motivasi yang memiliki nilai tertinggi dari hasil penelitian, dengan instrument saham yang menjadi pilihan Sebagian besar mahasiswa dalam berinvestasi di Pasar Modal.

Cara yang dapat diterapkan demi meningkatkan minat mahasiswa berinvestasi di pasar modal, yaitu peningkatan sumber daya manusia atau tenaga ahli dalam ranah kampus, memperbanyak fasilitas pendukung, adanya kerjasama dari pihak dosen pengampu dan Galeri Investasi Syariah UIN Antasari dalam menggiatkan semangat investasi di pasar modal contohnya memberikan kesempatan untuk mengenalkan investasi di pasar modal saat kelas berlangsung atau bisa juga memberikan kesempatan kunjungan yang lebih intensif ke Galeri Investasi Syariah UIN Antasari. Solusi lain juga dapat dilakukan berkaitan dengan mata kuliah yang berkenaan dengan pasar modal dapat menerapkan 3 SKS (2 SKS untuk pembelajaran teori dan 1 SKS untuk praktik langsung) serta adanya program ataupun kebijakan yang dibuat oleh pimpinan kampus dalam meningkatkan minat mahasiswa berinvestasi di pasar modal seperti kerjasama dengan TICMI, menyelenggarakan kegiatan terstruktur dan tidak terstruktur lainnya. Beberapa praktisi pasar modal juga menganjurkan adanya Follow Up untuk para dosennya, masih diperlukan pelatihan untuk para dosennya serta program kerja antara BEI Kantor Perwakilan Banjarmasin dan Galeri Investasi Syariah UIN Antasari bekerjasama dengan Bursa Efek Indonesia dan Phintaco Sekuritas yang lebih ditingkatkan lagi, tidak hanya itu program yang telah ada harus dijalankan secara rutin dan berkomitmen serta jika ingin mengadakan program baru pun harus berorientasi pada inklusi keuangan.

Penulis juga merekomendasikan agar Galeri Investasi di UIN Antasari yang merupakan hasil Kerjasama Perguruan Tinggi, Sekuritas dan Bursa Efek Indonesia dapat dimanfaatkan secara optimal oleh para mahasiswa khususnya, dan civitas akademika UIN Antasari pada umumnya, dalam menggali informasi secara lebih menyeluruh terhadap pasar modal. Selain itu, perlu adanya dukungan penuh dan konsisten terhadap operasional serta kegiatan edukasi dan sosialisasi yang dilakukan Galeri Investasi, baik dari Perguruan Tinggi, Sekuritas serta Bursa Efek Indonesia dalam upaya peningkatan literasi serta inklusi pasar modal di kampus.

Adapun untuk penelitian selanjutnya, riset ini dapat dikembangkan lagi dengan menggunakan variabel lain ataupun metode lain untuk mengetahui minat mahasiswa dalam berinvestasi.

\section{DAFTAR PUSTAKA}

Amhalmad, Iqbal, dan Agus Irianto. "Pengaruh Pengetahuan Investasi dan Motivasi Investasi Terhadap Minat Berinvestasi Mahasiswa Pendidikan Ekonomi Fakultas Ekonomi Universitas Negeri Padang." Jurnal EcoGen 2, no. 4 (2019): 734-46. 
Andriani, Sri. "Minat Investasi Saham pada Mahasiswa." Jumal Ekonomi dan Bisnis Indonesia 4, no. 1 (20 Juli 2019). https://doi.org/10.37673/jebi.v4i1.285.

Bakhri, Syaeful. "Minat Mahasiswa Dalam Investasi Di Pasar Modal." Al-Amwal: Jurnal Ekonomi dan Perbankan Syariah 10, no. 1 (16 Juni 2018): 146. https://doi.org/10.24235/amwal.v10i1.2846.

Dewi, Lusiana, dan Sri Yunawati. "Analisis Faktor-faktor yang Mempengaruhi Minat Mahasiswa untuk Berinvestasi di Pasar Modal." AKPEM:Jurnal Akuntansi Kenangan dan Pemerintahan 1, no. 1 (2019): 5.

Fajri, Hayatul. "Analisis Faktor-Faktor Yang Mempengaruhi Minat Berinvestasi Di Pasar Modal Syariah (Studi Kasus Mahasiswa Program Studi Ekonomi Syariah UIN ArRaniry Banda Aceh) Tahun 2018." Universitas Islam Negeri Ar-Raniry, 2018. https://repository.ar-raniry.ac.id/id/eprint/8292/.

Hasibuan, Siti Rahma. "Minat Investasi Mahasiswa Untuk Berinvestasi di Pasar Modal Syariah(Studi Kasus di Galeri Investasi Syariah UIN Sumatera Utara Periode 20172018).” Universitas Islam Negeri Sumatera Utara, 2018. http://repository.uinsu.ac.id/id/eprint/4025.

Hidayat, Lukman, Nusa Muktiadji, dan Yoyon Supriadi. "Pengaruh Pengetahuan Investasi Terhadap Minat Mahasiswa Berinvestasi Di Galeri Investasi Perguruan Tinggi." JAS-PT (Jurnal Analisis Sistem Pendidikan Tinggi Indonesia) 3, no. 2 (9 September 2019): 63. https://doi.org/10.36339/jaspt.v3i2.215.

IKAPI. Himpunan Peraturan Pasar Modal. Bandung: Fokusmedia, 2009.

Jahja, Yudrik. Psikologi Perkembangan. Jakarta: Kencana Prenada Media Group, 2011.

Karmila, Reni. "Analisa Faktor-Faktor yang mempengaruhi minat mahasiswa untuk berinvestasi di pasar modal (Studi Kasus Pada Seluruh Mahasiswa Yang Tercatat Sebagai investro di IDX Kota Jambi)." Universitas Islam Negeri Sulthan Thaha Saifuddin, 2018. http://repository.uinjambi.ac.id/id/eprint/673.

Martalena, dan Maya Malinda. Pengantar Pasar Modal. Yogyakarta: Penerbit Andi, 2011.

Muhammad. Manajemen Kenangan Syariah: Analisis Fiqh dan Keuangan. Yogyakarta: UPP STIM YKPN, 2016.

Nandar, Haris, dan Mustafa Kamal Rokan. "Faktor yang Mempengaruhi Minat Mahasiswa Berinvestasi di Pasar Modal Syariah Melalui Galeri Investasi Iain Zawiyah Cot Kala Langsa." KITABAH 2, no. 2 (2018).

Nandar, Haris, Mustafa Kamal Rokan, dan M. Ridwan. "Faktor yang Mempengaruhi Minat Mahasiswa Berinvestasi di Pasar Modal Syariah Melalui Galeri Investasi Iain Zawiyah Cot Kala Langsa.” KITABAH 2, no. 2 (Juli 2018): 179.

Noval, Muhammad, Rani Raharjanti, dan Musab A M Ali. "Ownership on Islamic Economic Perspective and Director Ownership on Sharia Companies with Moderation Roles of Independent Commissioners.” Ikonomika 5, no. 1 (2020): 26.

OJK. Buku Saku Otoritas Jasa Kenangan. 2 ed. Jakarta: OJK, t.t.

Rahadiyan, Inda. Hukum Pasar Modal di Indonesia. Yogyakarta: UII Press Yogyakarta, 2014. 
Situmorang, Masri, Riska Natariasari, dan Andreas. "Pengaruh Motivasi Terhadap Minat Berinvestasi di Pasar Modal dengan Pemahaman Investasi dan Usia Sebagai Variabel Moderat." JOM Fekon 1 (2014): 18.

Universitas Trunojoyo Madura, Maftukah Zain Syahroh, Tarjo, dan Achdiar Redy Setiawan. "Minat Investasi Mahasiswa pada Kompetisi Yuk Nabung Saham 2017 di Bursa Efek Indonesia (Pendekatan Mixed Methods)." Journal of research and application: accounting and management 4, no. 1 (1 September 2019). https://doi.org/10.18382/jraam.v4i1.005.

Wira, Desmond. Memulai Investasi Saham. Jakarta: Exceed, 2015.

Witakusuma, Gede Etyana, Putu Sukma Kurniawan, dan Edy Sujana. "Faktor-Faktor yang Mempengaruhi Perilaku Mahasiswa dalam Berinvestasi di Pasar Modal (Sebuah Tinjauan Empiris Pada Investor Pemula)." JIMAT Jurnal Ilmiah Mahasiswa Akuntansi) 9, no. 1 (2018): 12. 